\title{
CARLOS ALBERTO BITTAR: O AUTOR E SUA OBRA
}

\author{
Silmara Juny de Abreu Chinelato e Almeida \\ Professora Doutora do Departamento de Direito Civil da \\ Faculdade de Direito da Universidade de São Paulo
}

Conheci Carlos Alberto Bittar, em 1976, na Comissão de Redação da Enciclopédia Saraiva do Direito, coordenada pelo professor Rubens Limongi França. O autor era, naquela época, mestre em Direito Civil, advogado e iniciava carreira de professor, na Faculdade de Direito da Universidade de São Paulo. A partir de então pude acompanhar sua trajetória brilhante, firme em seus objetivos, caracterizada por notável e dedicada capacidade de trabalho.

A produção intelectual é das mais vastas entre os autores brasileiros e bastante diversificada nos assuntos que enfrenta, com maestria, como por exemplo: Direito de Autor, Direitos da Personalidade, Responsabilidade Civil - em seus vários aspectos, inclusive nas atividades nucleares Direitos do Consumidor, Reparação por Danos Morais, Software, Comunicações. As obras diversas consistem tanto em obras genéricas, de cunho didático, sobre Direito Civil, quanto em artigos que tratam de assuntos específicos e atuais, insertos em obras em colaboração muitas vezes coordenadas pelo próprio professor Bittar - em revistas especializadas brasileiras, estrangeiras e em jornais. Consistem também em monografias, que já se tornaram obras clássicas do Direito Civil brasileiro. Entre as obras genéricas, enfatizamos: Curso de Direito Autoral (1988), Responsabilidade Civil, Teoria e Prática (1989), Direito das Obrigações (1990), Direitos dos Contratos e dos Atos Unilaterais (1990), Contratos Civis (1990), Contratos Comerciais (1990), Direitos do Consumidor (1990), Direito de Família (1991), Direitos Reais (1991), Contratos Civis (1991), Teoria Geral do Direito Civil (1991), Direito das Sucessões (1992), Direito de Autor (1994) e Curso de Direito Civil, em dois volumes, obra esta elogiada pelo professor Rubens Limongi França, de quem eu e o professor Bittar fomos discípulos, que a comparou ao "Droit Civil", de Jean Carbonnier.

As várias monografias são caracterizadas pela profundidade científica, atualidade e pioneirismo nos temas escolhidos, todos de grande relevância. Como as obras genéricas, têm grande utilidade e importância tanto para professores e estudantes, quanto para os profissionais do Direito. Entre elas destacamos: Direito de 
Autor na Obra Feita Sob Encomenda dissertação de Mestrado, 1977 ; Direito de Autor na Obra Publicitária - tese de Doutoramento, 1981 -, Responsabilidade Civil nas Atividades Nucleares - tese de Livre-Docência, 1985 Direito de Autor nos Meios Modernos de Comunicação (1989), Direitos de Personalidade (1989), O Direito Civil na Constituição de 1988 (1991), Contornos Atuais do Direito de Autor (1992), Reparação Civil por Danos Morais (1993) - tese com a qual foi aprovado, com louvor, em concurso para professor titular de Direito Autoral na Faculdade de Direito da Universidade de São Paulo.

$\mathrm{Na}$ carreira universitária, iniciada em 1977, obteve todos os títulos acadêmicos: mestre, doutor, livre-docente e, em 1993, professor titular. Sou testemunha do grande respeito de que, merecidamente, gozou junto a seus colegas e alunos do Curso de Graduação e de Pós-Graduação. A exigência e rigor para com ele mesmo e para com os alunos, a dedicação e generosidade, qualificam Carlos Alberto Bittar como professor e orientador de mestrandos e doutorandos. Estes têm no mestre a orientação rigorosa, segura, profunda e entusiasta. A generosidade e espírito acadêmico se expressaram, ainda, através do incentivo e auxílio a seus alunos de Pós-Graduação, na publicação de trabalhos, contribuindo, assim, para que nova geração de autores se forme.

O doutor Bittar foi também conferencista renomado, tendo participado de conclaves no Brasil e no Exterior. Integrou várias entidades culturais, como a Associação Henri Capitant dos Amigos da Cultura Jurídica Francesa, o Instituto Interamericano de Direito de Autor e o R. Instituto de Advogados de São Paulo, na qualidade de conselheiro. Foi membro do Conselho Nacional de Direito Autoral (1980 a 1984), no qual proferiu inúmeros e notáveis votos que compõem a jurisprudência administrativa daquele órgão.

Tendo conquistado seus objetivos como autor consagrado, jurista e professor universitário, a carreira profissional do ilustre professor Bittar foi coroada de êxito, ao ser nomeado juiz do Primeiro Tribunal de Alçada Civil de São Paulo, pelo quinto constitucional. Em dois anos de judicatura, já se pôde reconhecê-lo como juiz plenamente vocacionado a sua nobre função, através de votos oportunos, pertinentes e cultos, que em muito contribuem para a boa e eficaz administração da Justiça.

A carreira jurídica de Carlos Alberto Bittar, em seus diversos aspectos, como jurista, professor, advogado e juiz, demonstra que com ela muito se 
enriquecem os profissionais do Direito, os alunos, a Ciência Jurídica, os administrados e o R. Poder Judiciário paulista.

A prematura morte do professor Bittar foi em 5 de maio de 1997, tendo deixado a esposa Rosa Bittar e os filhos Carlos Alberto Bittar Filho, Eduardo Carlos Bianca Bittar e Carla Bittar.

São Paulo, junho de 1998. 